\title{
Társadalmi informatika - információs társadalom mindenkinek?
}

Így hivatkozzon erre a cikkre:

Pintér Róbert. „Társadalmi informatika - információs társadalom mindenkinek?”. Információs Társadalom VI, 4. szám (2006): 134-141.

A folyóiratban közölt müvek

a Creative Commons Nevezd meg! - Ne add el! - Így add tovább! 4.0

Nemzetközi Licenc feltételeinek megfelelóen használhatók. 
Pintér Róbert

\section{Társadalmi informatika - információs társadalom mindenkinek?}

Social Informatics: An Information Society for All? - An International Conference in remembrance of Rob Kling IFIP-TC9 Human Choice and Computers-7

Maribor, Habakuk Kongresszusi Központ (Szlovénia)

2006. szeptember 21-23.

http://www.hcc7.org/

\section{A társadalmi informatika alapítója}

Az International Federation for Information Processing (IFIP) a Human Choice and Computers $(H C G)$ címú, rendszerint négyévente megrendezett konferenciasorozatának idei, hetedik rendezvényét a társadalmi informatika (social informatics) alapítója, Rob Kling emlékének szentelte. Az indianai professzor, Rob Kling küldetése - ahogy az egyik előadásban elhangzott - az volt, hogy intézményesítse az informatika társadalmi hatásainak kutatását, és hívja életre a társadalmi informatikát. A konferencia résztvevôi ezt az intézményesítési folyamatot vitték előre előadásaikkal, bemutatva a terület sokszínúségét és kijelölve a jövốbeli kutatás frontvonalait. A konferencia hivatalos oldala így fogalmaz: „Munkatársunk, Rob Kling fáradhatatlanul dolgozott azokon a témákon, amelyek a HCC-konferenciák középpontjában állnak. Az IFIP-TC9 alapító atyái közé tartozott. Sajnos 2003. május 15-én 58 éves korában itthagyott minket. A HCC hetedik konferenciájának fókuszában - az ő barátságára és szakterületünk iránti elkötelezettségére emlékezve - a »társadalmi informatika « fog állni, elsôsorban nem abban az értelemben, hogy tisztázni kívánjuk a Rob által meghatározott terület határait, hanem mindannak az összegyújitésével, amit ố tett azért, hogy elốre láthassuk, amit a jövóben tennünk kell az ô felfogásának jegyében, olyan előre mutató kutatások felkarolásával, amelyek lehetôvé teszik egy » mindenki számára elérhető «, humánus információs társadalom létrehozását, amelyben valóban »az ember az első « (people first)."

A háromnapos konferencia nyitó előadásai meglehetôsen személyes, bensôséges módon ismertették meg Klinget a közönséggel, és lehetôséget adtak az emlékezésnek mindazok számára, akiknek Kling a kollégája, kutatótársa, példaképe volt az elmúlt néhány évtizedben.

Chrisanthi Avgerou például, aki az IFIP-nek a számítógépek és a társadalom viszonyával foglalkozó munkacsoportját (TC9 - Relationship between Computers and Society) jelenleg vezeti (ezt a tisztet egykoron maga Kling is betöltötte), az 1980-as években ismerkedett meg Kling munkásságával, amikor a doktori értekezését készítette. Ekkor került a kezébe a második HCC-konferencia kiadványa, és ez volt az elsô eset, amikor az informatikai fejlődés társadalmi kritikájával találkozott, ami nagyban meghatározta 
késóbbi gondolkodását. Ebben a kötetben olvasott életében először valamit Rob Kling írásai közül. ${ }^{1}$ A mostani konferencián tartandó beszédére készülve újra elókereste a cikket, és arra a következtetésre jutott, hogy miközben a témák (pl. a demokrácia, a privacy vagy az etika kérdései) változatlanul megmaradtak, a kutatások relevanciája és mélysége megnốtt. Ennek megfelelően a kapcsolódó kérdéseket is egyre tisztábban próbálják látni és láttatni, segítve a felmerülố társadalmi problémák megoldását. Idóközben kialakult egy kifejezetten a társadalmi informatikát kutató réteg is: ma már javarészt nem mérnökök beszélnek a témákról, hanem a téma avatott szakértôi, akik fó kutatási területükként foglalkoznak a társadalmi informatika kérdéseivel. A tudományos háttér persze továbbra is sokféle, megtalálhatók benne a szociológia, a politikatudomány és az antropológia mellett a már említett mérnöktudományok is...

A megnyitót követốen az elsố szekcióban John L. King, a Michigani Egyetem kutatója „A társadalmi informatika társadalmi konstrukciója” címmel Kling életútján, személyes érdeklődésének alakulásán és egyéni szocializációján keresztül mutatta be az alapító munkásságát. King a diákja volt Rob Klingnek, majd együtt dolgozott vele az Irvine iskolában, ahol az 1970-es években kezdődött meg a társadalmi informatika kutatása.

Kling személyes indíttatása és fó kutatási témái az 1960-as évek végéról datálódnak. Akkoriban sok könyv foglalkozott azzal a kérdéssel, hogy vajon a technológiai fejlódésnek csak előnyei vannak-e, mint ahogy azt akkor (is) előszeretettel hangoztatták. Ugyanekkor indult el hódító diadalútján a mikrochip, megszületett a Moore-törvény és megjelentek az elsố számítástechnikai termékek. Nem sokkal késóbb alakultak meg az első, ma már világhírú cégek, köztük a Microsoft is. Nagyon gyorsan születtek új termékek, amelyeket az emberek azonnal használni is kezdtek, pedig nem sokkal korábban a legtöbben még úgy hitték, hogy az ilyen eszközök csak a gyermekeik számára lesznek hozzáférhetók. Fontos adalék az is, hogy ezeket az új eszközöket leggyakrabban olyan fiatalok hozták létre, akik egyfajta ellenkultúrát képviseltek a társadalmon belül: elsốsorban morálisan közelítettek a világhoz, mert jobbá akarták tenni azt, és nem a meggazdagodáson törték a fejüket.

Rob Kling elsố tudományos cikke Analogy and Representation címmel 1966-ban jelent meg. ${ }^{2}$ Ezután Kling 1974-ig több írásában foglalkozott a technológiai fejlödéssel, egy 1974-ben készült tanulmányát (Fuzzy Planner) azóta is változatlan kedvvel idézik világszerte. ${ }^{3}$ Még eközben elkezdett a komputerizáció társadalmi hatásaival is foglalkozni, 1973-ban és 1974-ben több cikket is írt ebben a témában. ${ }^{4} 1974$ után munkásságában már a társadalmi vonulat volt a legerôsebb, három cikket is írt azokról a politikai hatásokról, ${ }^{5}$ amelyeket a számítógépek alkalmazása a társadalmi és politikai programokra

\footnotetext{
${ }^{1}$ Kling, R. (1979). Social issues and impacts of computing: From arena to discipline. Paper presented at the $2^{\text {nd }}$ Conference on Computers and Human Choice (HCC-2). Baden (Austria).

${ }^{2}$ Kling, R. (1966). Analogy and representation: Artificial Intelligence Center. Stanford Research Institute.

${ }^{3}$ Kling, R. (1974). Fuzzy planner. Journal of Cybernetics, 4(2), 105-122.

${ }^{4}$ Kling, R. (1973). Towards a person-centered computer technology. Paper presented at the ACM National Conference. Atlanta, Georgia.

Kling, R. (1973, October). Notes on the social impacts of ai. SIGART Newsletter, 42, 35-40.

Kling, R. (1974). Computers and social power. Computers and Society, 5(3), 6-11.

${ }^{5}$ Például Kling, R. (1978). Information systems in public policy making: Computer technology and organizational arrangements. Telecommunications Policy, 2(1), 22-32.
} 
gyakorol. Ezt követốen kb. 1978-tól az elméleti munka felé fordult és hozzálátott a társadalmi informatika elméleti alapjainak lefektetéséhez. ${ }^{6}$ Ezzel párhuzamosan számos szakmai egyesület és társaság tagja is lett, 1976-tól vezette például az IFIP-TC9 munkacsoportját. Az 1980-as években már szinte kizárólag az elméleti kérdésekkel foglalkozott. ${ }^{7}$ Ekkor indult el igazán az egyetemi karrierje is. Haláláig számos helyen dolgozott, és több terület is hatással volt munkásságára:

- Társadalmi informatika (Indiana University)

- A számítástechnika társadalmi analízise (University of California)

- Mesterséges intelligencia (University of Wisconsin - Madison)

- Elektrotechnika, számítástechnika és mesterséges intelligencia (Stanford University)

Meghatározó szerepe volt az indianai Center for Social Informatics létrehozásában, amely ma már az ố nevét viseli. ${ }^{8}$ Rob Kling öröksége, hogy a társadalmi informatika oktatása intézményesült, elismerték mint önálló kutatási irányt, és új kutatási koncepciók születtek a terület szisztematikus feltárására.

\section{Fókuszban a társadalmi informatika kutatása}

A konferencián persze nemcsak Rob Kling munkásságával foglalkoztak az elôadók, hanem magukkal a társadalmi informatikai kutatási kérdésekkel is, sốt, tulajdonképpen - a nyitó napi visszaemlékezés és a zárszóban elhangzott meleg szavak kivételével, amelyek mintegy keretbe fogták a rendezvényt - leginkább az általuk felvetett témákkal adóztak Kling emlékének.

A háromnapos szakmai program részben plenáris üléseken zajlott:

1. az információs és kommunikációs technológiák (ICT) a gyógyászatban és az egészségügyi rendszerben: a társadalmi, etikai és jogi kérdések vizsgálata;

2. a társadalmi informatika oktatása.

A plenáris eseményeken túl azonban javarészt két egymással párhuzamosan múködố szekcióban folyt a munka, amelyek a következố témákkal foglalkoztak:

1. etika és kultúra,

2. politika és törvény,

3. információs társadalom és ICT-politika,

4. módszerek és koncepciók,

5. gazdasági, szervezeti és technikai kérdések.

${ }^{6}$ Például Kling, R. (1978). Six models for the social accountability of computing. Information Privacy, $1(2), 62-70$.

${ }^{7}$ Kling részletes bibliográfiáját lásd http://rkcsi.indiana.edu/index.php/rob-kling-bibliography

${ }^{8}$ Rob Kling Center for Social Informatics: http://rkcsi.indiana.edu/

${ }^{9}$ Ebben a szekcióban mutatták be a múegyetemi gyakorlatot is, a panel nyitó elóadásaként: $Z$. Karvalics László és Juhász Lilla: Teaching Social Informatics for Engineering Students. 
Ez az írás múfajánál és terjedelmi korlátainál fogva nem alkalmas az elhangzottak sokszínúségének teljes visszaadására, de a rendezvény idejére megjelent konferenciakiadvány (Proceedings) ${ }^{10}$ kárpótolhatja a távolmaradókat is. A továbbiakban ezért csupán két érdekes előadás és egy panel gondolataiból szemezgetünk röviden, nem törekedve a teljességre. ${ }^{11}$

\section{A gyermekek képe az információs társadalomról}

Izgalmas előadást tartott Jacques Berleur, a TC9 korábbi energikus vezetôje, aki az információs társadalommal foglalkozó világ-csúcstalálkozó (World Summit on the Information Society, WSIS) alkalmából meghirdetett gyermekrajzverseny díjazottjainak pályamunkáiból mutatott be néhányat a közönségnek, hogy a mai kor gyermekeinek az információs és kommunikációs technológiákkal kapcsolatos naiv, néhol utópikus világképét elemezze. A WSIS 2003-as genfi fordulójára meghirdetett rajzversenyre 1600 alkotás érkezett be mintegy 38 országból. Mit ábrázoltak ezek a képek? Az alkotások tükrében az információs és kommunikációs technológiák

- segítik az embereknek megismerni a világot,

- kézzelfoghatóvá teszik a kulturális sokszínúséget,

- fejlesztik az életminőséget,

- egyszerúbbé teszik a részvételt a helyi kormányzásban,

- elôsegítik az információcserét,

- segítenek kommunikálni a különbözố kérdésekról,

- de hozzájárulnak a digitális szakadék kialakulásához is.

A fentieken kívül több rajz témájában megjelentek olyan más kérdések is, mint például az emberi jogok, az értékek megosztása, a szabadság stb..

A rajzok nagy többsége technológiabarátnak mondható, de kritikus ábrázolások is akadnak közöttük. Fókuszukban egyfajta technológiai utópizmus és antiutópizmus, a remény és a ,, borzalom” áll.

Az előadásnak szándékoltan nem volt konklúziója, mivel kicsi volt a minta és intuitív az elemzés, de az elôadó felhívta a figyelmet bizonyos kitapintható trendekre:

- Az ábrázolás témája a legtöbb esetben a kommunikáció, azon belül is a telefon, tehát a gyermekek figyelmét nem elsôsorban az új eszközök ragadják meg.

- A középpontban az értékek állnak (béke, egység, egyetemes hozzáférés, multikulturalizmus, emberi jogok, a másság tolerálása).

- Hangsúlyosan jelenik meg az életminốség és annak javítása.

- A kulturális sokszínúség fontossága meghatározó elem.

- Cél a digitális szakadék csökkentése.

${ }^{10}$ Social Informatics: An Information Society for All?, Human Choice and Computers-7. Jacques Berleur, Markku Nurminen, and John Impagliazzo, Eds. IFIP-TC9 International Conference in remembrance of Rob Kling. Maribor (Slovenia), 21-23 September 2006. Springer Science \& Business Media, 2006, Series: IFIP vol. 223.

${ }^{11}$ A konferenciáról ennél részletesebb beszámoló olvasható a Konferencia Tùdásbankban, lásd http://www.konferencia-tudasbank.hu 
Jacques Berleur elôadásának végszavában a résztvevốk segítségét kérte ahhoz, hogy a jövố nemzedék álmai és vágyai ne maradjanak álmok és vágyak csupán - ezt az informatika társadalmi hatásaival kritikusan foglalkozó szakmai rendezvények (köztük a HCC-7) is nagyban támogathatják.

\section{A mindenhol jelen lévő számítástechnika mint a tudományos elemzés eszköze és tárgya}

Roberta Lamb (University of Hawaii, Honolulu; University of California, Irvine, USA) egy meglehetôsen elméleti jellegû́ és helyenként nehezen követhetô, de annál izgalmasabb előadást tartott a számítástechnika mindenhol jelenlévőségéról és - ezt példázandó - a tudományos kutatásba való beágyazódásáról.

A legújabb kutatásokban nem választják el élesen egymástól az embereket és a technológiát. Az ember és a technológia egységben való kezelését az indokolja, hogy ma egyik sem létezik a másik nélkül. Ha ezt metaforákban képzeljük el, akkor a Star Trek sorozatból megismert borgok, a Terminátor és egyéb hollywoodi képek jelenhetnek meg elóttünk. Ezek persze a jelenlegi trendek negatív felfokozásai, de jól jelzik, hogy az ember ma már több mint egyszerú biológiai lény, az új (információs és kommunikációs) eszközök elválaszthatatlanok tólünk. Kérdés persze, hogy hol van az interfész ember és technikai eszköz vagy ember és ember között. Hol húzódnak a társadalmi szereplók közötti határok?

A legtöbb tudományos érvelés minden kritika ellenére mind a mai napig az ember és a technológia, a társadalom és a természet dualizmusában gondolkodik. A közgazdaságtanban például az ember és a technológia együttese áll szemben a természettel. Bruno Latour szerint viszont az emberiség (az ô meghatározásában a „techno-humanitás" mint munkaerố, technikai tudás és technológia) egységben kezelendó a természettel, mivel kölcsönös kapcsolatban állnak egymással (reciprocitás, szimmetrikus kapcsolatok).

$\mathrm{Az}$ ember viszont nem tudja egész környezetét egységben kezelni, hanem kisebb alegységekre bontja vagy leszúkíti azt (ismét hollywoodi képpel élve: a „Bubble boy” címú, 2001-ben készült amerikai film juthat az eszünkbe). ${ }^{12} \mathrm{Ez}$ a leszúkítés azonban olyan leegyszerúsítés, amely nem a megfelelő helyén kezeli a technológiát. A másokkal való együttmúködés a különbözố nagy szervezetekben (pl. a hadseregben, a tudományos intézményrendszerben stb.) ugyanis több alrendszerból álló összetett technológiai struktúrák felépítését és használatát igényli.

Az elôadó kézzelfogható példákat is hozott, hogy fejtegetése ne legyen túl elvont. Ezek szerint például a mindenütt jelen lévố számítástechnikának köszönhetôen a tudósok is „új módon” múvelik a tudományt. Az oceanográfia például korábban alapvetốen a tengeri felfedezésekre épült, a terepmunka azonban - elsôsorban az idójárás szeszélyei miatt - kiszámíthatatlan és nagyon veszélyes. A veszélyek kiküszöbölésére az elmúlt másfél évtizedben új eszközöket fejlesztettek ki, amelyekkel egyrészt a felszínról, másrészt akár távolról is elvégezhetố a kutatás: szenzorokat helyeznek ki, amelyek fo-

${ }^{12}$ Bubble Boy, rendezte Blair Hayes (2001). 
lyamatosan kommunikálnak az otthoni intézettel, tehát akár rögtön, már a felfedezés folyamatában is közzétehetók az eredmények. Mindezt az 1990-es évek technológiája tette lehetôvé. Ezek az eszközök mára meghatározó tudományos technológiákká váltak, amelyek beágyazódnak a kutatásba, és mindenütt jelen vannak, más tudományos területeken is.

Az előadó egy másik példája egy csillagászati projekt (Canada-France-Hawaii Telescope Legacy Survey, CFHLS) volt: az ebben dolgozó nemzetközi tudományos közösség tagjai állandóan ellenőrzik bolygónk időjárását, hogy előre jelezhessék, éjszakánként az éppen futó kutatások mely részei hol végezhetók el. Az a bonyolult folyamat, melynek során az adatokat begyújtik, ellenôrzik, rendszerezik és feldolgozzák, majd terítik, elemzik és kommunikálják az eredményeket, javarészt automatizált, mégis az emberek tartják össze, hiszen nem egyetlen varratmentesen összefüggő, egységes rendszerról van szó, hanem nehezen koordinálható és törékeny folyamatok sokaságáról.

Mindent összevetve hatalmas szolgáltatási infrastruktúra áll a tudósok rendelkezésére, legalábbis az ún. „nagy tudomány” (big science) kutatási területein. A hagyományos kutatás átalakul, az ICT ugyanis lehetôvé teszi olyan jelenségek valós idejú, „esemény-válasz" jellegú megfigyelését is, amelyek elöre megjósolhatatlanok, s mindez átalakítja nemcsak a tudományos megfigyelés és az elemzés módszereit, hanem az idó és a temporalitás fogalmát is.

Az előadás végén - tisztázó kérdésre adott válaszként - elhangzott az is, hogy ez a modell a társadalomtudományokban persze csak nehezen, vagy egyáltalán nem követhetô, hiszen az emberek folyamatos megfigyelésével kapcsolatban a privacy sérthetetlenségéból adódó etikai kérdések merülnek fel. Ennek ellenére a társadalomtudományi kutatások terén is vannak próbálkozások különféle szenzorok (pl. RFID-csipek, kamerák stb.) alkalmazására, ezek azonban egyelóre még nem alkotnak olyan szisztematikusan felépített egységes rendszereket, mint például a csillagászatban vagy az oceanográfiában.

\section{Diákfórum a "tisztességes" globalizációért"}

Az úgynevezett fair globalization fogalmát 2004 februárjában definiálta a Nemzetközi Munkaügyi Szervezet (International Labour Organiঞation, ILO), s késóbb az ENSZ közgyúlése is elfogadta ezt a meghatározást, melynek a legfontosabb tartalmi elemei a következók:

- demokratikus és effektív állam,

- fenntartható fejlődés,

- produktív és egyenló piacok,

- tisztességes és méltányos szabályok,

- szolidaritás,

- nagyobb felelősség az emberek iránt,

- szorosabb partneri viszonyok,

- emberközpontúság.

${ }^{13}$ Mivel a konferenciát szervezô IFIP maga is az ENSZ szervezete (alapítói között van az UNESCO), ezért „kézenfekvô” volt a témaválasztás a diákfórum számára. 
A konferenciával párhuzamosan sor került egy nemzetközi diákfórum megrendezésére is, melynek szervezối a tisztességes globalizáció és az ICT viszonyát túzték napirendre. Elốre meghatározott elvek alapján 12 témát választottak ki, amelyeket a résztvevôk kisebb csoportokban tárgyaltak meg.

A fórum eredményei a következó állításokban foglalhatók össze:

- A globalizáció folyamatában az ICT-nek elő kellene segítenie az átláthatóságot és a szabad választást. Ennek hatása van az öntudatosságra, valamint a spirituális fejlődésre is.

- Az ICT alkalmazása segítheti az önkritikát és a nemzeti identitás védelmét. Mindenkit integrálni kell, de csakis a saját érdekeit és érdeklődését figyelembe véve.

- A tisztességes globalizációt az szolgálná, ha a „törvényes” egyúttal azonos lenne a „jó" fogalmával, ha a tudás keresésének és megszerzésének a lehetôsége mindenki számára megadatna. Ehhez az ICT-vel (is) támogatott kétirányú kommunikációra van szükség, ami hatékonyan hozzájárulhat mindenki lehetôségeinek és képességeinek a gyarapításához (empowerment).

A diákok - eltérve az eredeti célkitúzéstól - nemcsak az ICT és a globalizáció viszonyát vizsgálták, hanem a globalizációt általában is, így viszont nem tudtak minden aspektusra kitérni, és úgy döntöttek, hogy folytatják a fórumon megkezdett munkát: legközelebb 2006 novemberében az Internet Governance Forum kapcsán gyúlnek össze, Athénban.

\section{Befejezés: merre tovább?}

A konferencia zárásaként a plenáris előadók közül Roberta Lamb elmondta, hogy a konferencia helyszíne jelzésértékú, mert javarészt itt, Szlovéniában kezdődött el a társadalmi informatika kutatásának nemzetközivé válása és szakmai közösségének kialakulása egy IFIP konferenciával. Európában Kling nagyon sok támogatást kapott: kutatásainak irányát itt sokkal inkább elfogadták, mint bárhol másutt a világon.

Zárszavában Jacques Berleur, a konferencia egyik szervezóje fontos tanulságként emelte ki, hogy a területen hosszabb távra elốre tekintve számos új téma fog felmerülni a globalizációval és az új technológiákkal összefüggésben. Ez azonban oda vezet, hogy ma már nem lehet többé generalista szemlélettel közelíteni a kérdésekhez, ami húsz évvel ezelőtt még lehetséges, sốt szükséges is volt. Részben ennek is köszönhetô, hogy az egész kutatási terület ugyan korántsem konzisztens, viszont megmaradt a „mozgalmi” jellege. A konferencia egyik célja ezért a vizsgált területek pontosabb behatárolása és az elméletek tisztázása volt. Szükségessé vált a megfontolt eloorelépés a kutatott terület kereteinek további meghatározásában, melynek során el kell dönteni, hogy mi tartozik ide, milyen elméletek, kutatási módszerek stb. tartoznak a társadalmi informatika „illetékességi köréhez". Sok kérdés nyitva maradt, ez pedig alapot ad hasonló konferenciák megrendezéséhez a jövóben is.

A jelen beszámoló befejezéseként fontos hangsúlyozni „az emberek elsóbbségének" (people first) a konferencia berekesztésekor is kiemelt alapelvét, ami a társadalmi 
informatika egyik legfontosabb szervezố elve, s így a konferencia egészét áthatotta. A további fejlődéshez azonban meg kell erôsíteni az ICT használatával kapcsolatos kritikai látásmódot - állította Lamb. Mindeközben azonban nem lehet elválasztani egymástól az elméletet és a gyakorlatot: olyan módszerekre van szükség, amelyek az elméletból táplálkoznak, és olyan elméletekre, amelyekbe beágyazódnak az empirikus kutatások eredményei. A társadalmi informatikusok akkor végzik jól a munkájukat, ha az eredményeiket mások is felhasználják, s így azok eljutnak az emberekhez, és segítenek nekik. Ehhez viszont olyan tudományos közösségre van szükség, mint amilyennek a kiformálódásához ez a konferencia is hathatósan hozzájárult. 